This item was submitted to Loughborough's Research Repository by the author.

Items in Figshare are protected by copyright, with all rights reserved, unless otherwise indicated.

\title{
Teachers' perspectives on collaboration with didacticians to create an inquiry
} community

PLEASE CITE THE PUBLISHED VERSION

http://www.tandfonline.com/doi/abs/10.1080/14794800902732209

PUBLISHER

Routledge @ British Society for Research into Learning Mathematics

VERSION

AM (Accepted Manuscript)

LICENCE

CC BY-NC-ND 4.0

\section{REPOSITORY RECORD}

Bjuland, Raymond, and Barbara Jaworski. 2019. "Teachers' Perspectives on Collaboration with Didacticians to Create an Inquiry Community”. figshare. https://hdl.handle.net/2134/8806. 
This item was submitted to Loughborough's Institutional Repository (https://dspace.lboro.ac.uk/) by the author and is made available under the following Creative Commons Licence conditions.

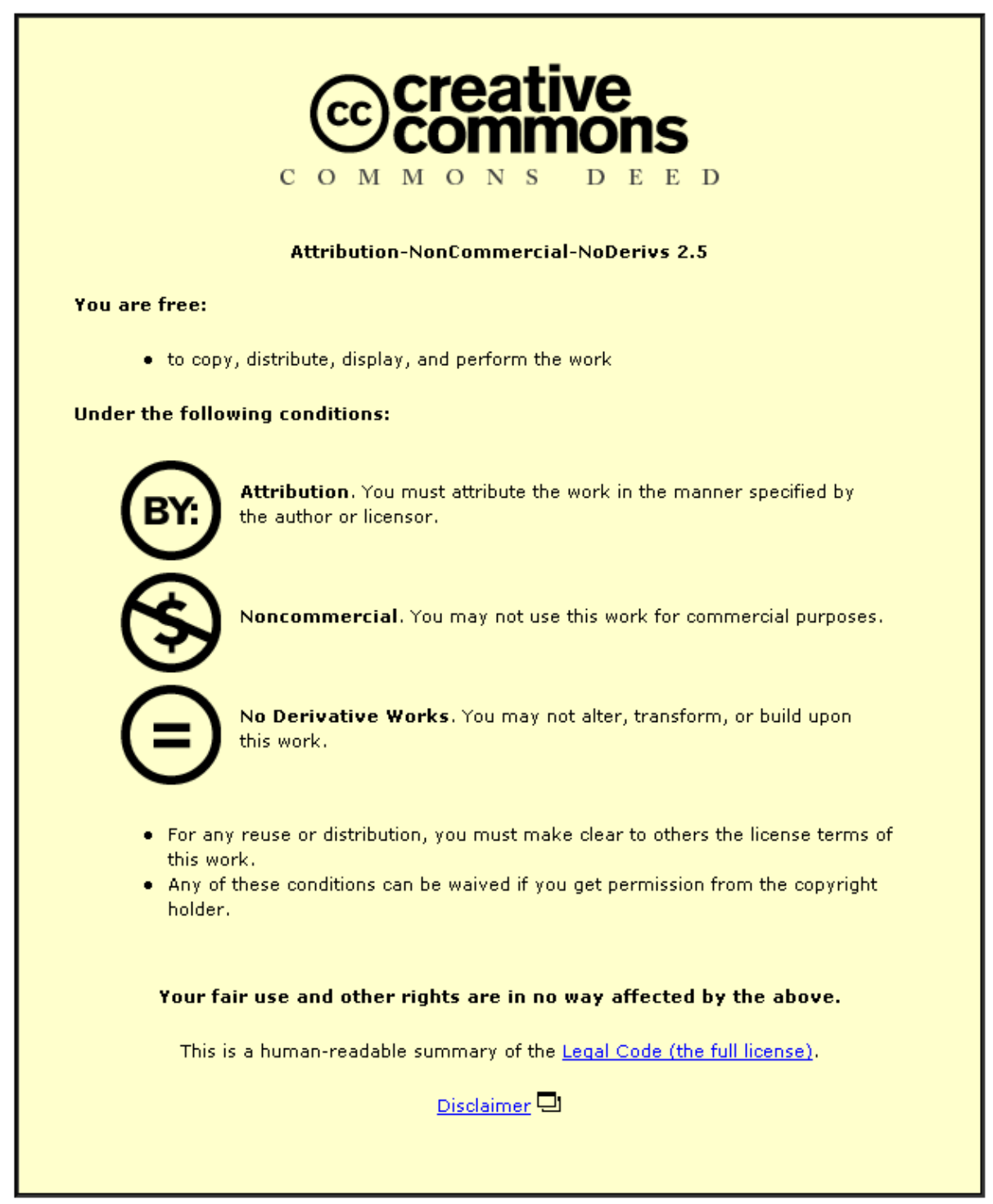

For the full text of this licence, please go to: http://creativecommons.org/licenses/by-nc-nd/2.5/ 


\title{
Teachers' perspectives on collaboration with didacticians to create an inquiry community
}

\author{
Raymond Bjuland, University of Agder (UiA), Norway \\ Barbara Jaworski, Loughborough University, UK \& University of Agder, \\ Norway
}

A research and development project Learning Communities in Mathematics $(L C M)^{1}$ was designed to create opportunities for 'co-learning inquiry' between mathematics teachers in eight schools and didacticians in a university in Norway (UiA). The focus has been on improving mathematics teaching and learning at school levels from lower primary to upper secondary and on the developmental processes and partnerships involved. A central aim was to create a community of inquiry through which aspects of mathematics teaching and learning could be explored and through which both teachers and didacticians could learn in practice. The project included three, one-year phases of joint activity. At the end of Phase II, didacticians led focus group interviews with teacher teams to gain insights into schools' and teachers' perceptions of the project and its activity. We report on insights into how teachers thought about the activities of the project and what an inquiry community looks like in terms of the learning of those involved.

\section{Project design - the theoretical basis \\ Research and development}

In the project, Learning Communities in Mathemtics (LCM) didacticians ${ }^{2}$ at the University of Agder (UiA) wished to explore with teachers ways in which learning and teaching of mathematics in classrooms could be improved. The project was intended to be both a research and development project, not only in terms of researching the developmental process, but of the research itself acting as a strong developmental tool (Jaworski 2003). We expected that research would provide both generalizable knowledge of an academic form and practically-based knowledge which would influence practice in classrooms and in teacher education. Thus didacticians and teachers would be both practitioners and researchers. This was the main reason for using the term 'didactician' rather than 'educator' or 'researcher', since we wanted to acknowledge teachers also as both educators and researchers. Thus the relationships between research and practice, between researchers and practitioners would be complex. In terms of Wagner's (1997) typology of relationships between researchers and practitioners, we thought these would fit best into what Wagner calls a 'co-learning agreement' mode. We based our design on notions of co-learning inquiry (Jaworski 2004).

\section{Co-learning inquiry}

Mathematics education has a long history of using inquiry approaches and methods in mathematics learning and teaching. Inquiry includes ideas of investigation and exploration, questioning, problem solving and generally of seeking for knowledge and understanding 
both in mathematics and in processes of learning and teaching mathematics (Bjuland 2007; Borgersen 1994; Cobb, Wood and Yackel 1993; Jaworski 1994; Mason, Burton and Stacey 1982; Polya 1945). Further, inquiry equates with research, particularly where practitioner research/inquiry is in focus (Cochran Smith and Lytle 1999; Elliott 1991; Jaworski 1998; Mason 2001). The design of the LCM project incorporated ideas of inquiry at three levels: in mathematics in the classroom, in the design of tasks for the classroom and exploration of their value for pupils' learning, and in the research and developmental process as a whole. Thus, the project sought to inquire into how didacticians and teachers might use inquirybased mathematical tasks to enhance mathematical understandings and provide for better learning of mathematics.

We sought to develop inquiry communities of teachers and didacticians through which we could inquire and learn together. The idea of inquiry community develops from the idea of participation in a community of practice as theorized by Wenger (1998). We accept Wenger's notion of 'belonging' to a community of practice as encompassing three elements: engagement, imagination and alignment of participants. A community of practice becomes a community of inquiry when participants' alignment becomes critical. That is, participants align themselves with practices within their community, while at the same time inquiring into and becoming critical of the practices in which they engage. So where teachers and didacticians as practitioners are concerned, each group belongs to its own community of practice and works within that community, following its activity and norms, while at the same time questioning what is achieved, and how, and introducing new elements for critical consideration. Earlier papers explain these theoretical principles in greater detail (e.g., Jaworski 2006).

\section{Developmental research}

The research process as we conceived it would use an inquiry cycle having much in common with cyclic processes in action research (e.g. Elliott 1991) and design research (e.g. Kelly 2003; Wood and Berry 2003). Teachers and didacticians would design tasks for the classroom, teachers would use the designed tasks with their pupils, video data from lessons would be studied by both teachers and didacticians through a reflective/analytic process and reflective outcomes would feed back to future planning. The inquiry cycle would be an important tool in the process of critical alignment, both promoting critical reflection on practice and providing a structure for it. Both teachers and didacticians would bring important knowledge to the design process and both would be active in exploration within the cycles of activity. However, since the inquiry cycle did not fit strictly within either action or design research models, we preferred to refer to our activity as developmental research, while recognizing its strong links to the other established modes and emphasising the strong intention that research should promote development (Goodchild, 2008). As well as the developmental research cycles, the progress of development was researched, with data collection and analysis taking place throughout the project relevant to a set of research questions related to the main aims of the project. Focus group interviews with teachers (FGI) were a part of this research process. 


\section{Operationalization}

\section{Recruitment of schools}

The project design was made by didacticians prior to submission to the research council to meet a tight deadline. Only after acceptance by the research council and the promise of funding was it possible to seek the cooperation of schools. At the first LCM meeting on 6th January 2004, didacticians started to think about which schools might collaborate in the project. We thought initially of six schools, possibly with two each in the age ranges 1-7, 810 and 11-13, and discussed a variety of factors: type of school, location, connections to UiA, socio-economic factors, and important characteristics of a school such as teachers who we might expect to work well with us. We drew up a list of about 11 schools and sent out letters of invitation. One important requirement for participation was that a minimum of three teachers from each school would attend workshops and meetings at UiA. In addition, it was proposed that, in any school, the teachers would work together as a team, taking initiative in designing tasks and activities for the classroom. They would teach lessons that they had designed, observing each other wherever possible, and collaborate with didacticians from UiA to study the teaching and learning that took place. In response to these letters and other contacts, seven schools agreed to join the LCM project and one further school was absorbed later into LCM.

\section{Three phases of activity}

The project had three field-based phases, each of one school year, with six workshops spread uniformly across each of Phases 1 and 2, and four workshops in Phase 3 . Phase 3 began with a conference to present the work of the project to participants from schools and colleges both locally and further afield in Norway. Each school made a presentation at this conference and conference activity formed the starting point for Phase 3. The FGI took place towards the end of Phase 2 and around the time when schools were thinking about their planning for an input to this conference.

According to the project design, the team of didacticians ${ }^{3}$, in consultation with teachers, should plan workshops that would lead activity and from which work in schools would follow. The first phase of activity was designated as one of 'community building' in which teachers and didacticians would learn to work together with clear aims. The six workshops each had a central focus on mathematics, and on related didactical and pedagogic issues. Mathematical tasks were designed by didacticians to enable teachers and didacticians to work side by side doing mathematics and talking about it. Workshops included plenary and small group activity.

Throughout the first phase and continuing to second and third phases, workshop activity evolved as relationships between teachers and didacticians developed and teachers participated and commented on the nature of activity and participation. Although workshop planning mostly took place at the university, teachers' views were constantly a guiding factor in decision-making and design. Phase II became a phase of planning for the classroom, and Phase III focused on schools' developmental goals for mathematics teaching and learning. Throughout, the meaning of 'inquiry' was discussed and debated in connection with activity in workshops and schools. 
Associated school work followed from the workshops, with school teams operating in a range of modes according to particular wishes, characteristics and circumstances. Didacticians visited schools according to local agreements with the teachers. Further details can be found in Jaworski (2005) and Jaworski, Fuglestad, Bjuland, Breiteig, Goodchild, and Grevholm (2007).

\section{Focus group interviews (FGI) and their analysis}

Towards the end of Phase II (Spring 2006), semi-structured focus group interviews were carried out at each of the eight schools based on the following overall question: what are the outcomes of two years of participation in the LCM project? They aimed to document schools' and teachers' perspectives of and from the project at this stage of activity. The meetings comprised the particular school team, often together with the Principal or the Vice Principal, and two didacticians from UiA. Didacticians had drawn up a set of 12 basic questions addressing elements of the LCM programme: workshops, school teams, innovation in classrooms, notions of inquiry and community and reasons for joining the project. Questions also explored what had been seen as valuable or problematic, views on respective roles of teachers and didacticians, and schools goals for the future in learning and teaching mathematics. Each question was just a starting point and discussion among members of each FGI group was encouraged. In any interview, didacticians asking the questions adjusted them according to directions of dialogue.

Based on the audio recordings, the analysis started with data reduction of the interviews in which the focus group questions were used as categories to get an overview of the conversation. All the interviews were transcribed turn by turn, indicating the speaker that held the floor, to allow more in-depth analysis where desired. The basic categories allowed an initial sorting of the data according to, for example, views expressed on workshops, or positive and negative reactions to notions of inquiry-based tasks in classrooms. Within these categories, and more broadly, researchers took a grounded approach to transcript data, coding and categorizing more finely within and across the guiding categories.

As described above, analytic categorization took place in two directions: from initial categories to related data; and in a grounded approach from data to categories, original or emergent. In this paper, we focus on the following areas of findings from analysis which seem particularly informative with regard to project participation and learning:

- Teachers' reasons for joining the project;

- Teachers' perceptions of the project, positive and negative;

- Different roles of teachers and didacticians.

Findings suggest how schools, teachers and didacticians have learned from having participated in the project and provide insights into mathematics teaching and learning development in collaborative projects more generally.

\section{Details of the schools}

In this paper, wWe draw mainly on data from three schools, two at primary level and one including both primary and lower secondary. Brief details follow.

Stjernen Primary School (Grades 1-7) has about 350 pupils. Before entering into the LCM project, some teachers from Stjernen were also involved in a project called 
'Fun with mathematics' in which one of the outcomes of this work was the 'Phase model'. This model describes how new mathematical topics can be introduced by means of an inquiry-based approach to teaching.

Strand Primary School (Grades 1-7) consists of about 310 pupils. Before being part of the LCM project, the school had started to organise some inquiry-based teaching in mixed grade levels with three school landscapes: Grades 1-2, Grades 3-4, and Grades 5-7.

Fjellet School (Grades 1-10) consists of about 250 pupils. This school had cooperated with UiA in earlier projects. Fjellet is a combined primary and lower secondary school with only one class at each grade level.

Table 1 shows when the three focus group meetings were held and the persons present.

Table 1: Schools, teachers and didacticians taking part in each FGI

\begin{tabular}{|l|l|l|}
\hline Stjernen Primary School & Strand Primary School & Fjellet School \\
$13^{\text {th }}$ March, 2006 & 31 & 23 \\
(FG_060313) & (FG_060331) & (FG_060323) \\
\hline Teachers: & Teachers: & Teachers: \\
Agnes, Egil and Fredrik & David and Edvard & Sylvi and Markus \\
\hline Principal & Arnold/Vice Principal & None from administration \\
\hline Didacticians: & Didacticians: & Didacticians: \\
Eli and Alf & Leo and Odd & Eli and Tor \\
\hline
\end{tabular}

Note: in the FGI meeting at Fjellet School there was no person present from the school administration. However, Markus, an experienced Secondary School teacher, was well informed about administrative issues. Arnold was both vice principal and a teacher-participant in LCM.

All data has been translated from the original Norwegian by the authors. In quotations from data, each turn is numbered to indicate where in the interviews quotations have been selected. Sometimes a quotation is condensed from several turns as numbers indicate. The text in brackets provides extra contextual information to help the reader understand better what has been said. Three dots indicate that some text has been omitted.

\section{Findings from analysis of the Focus Group Interviews}

\section{Teachers' reasons for joining the project}

The contextual information above indicates that all three schools had been engaged in other projects that were aiming at developing the teaching and learning of mathematics. In the case of Fjellet, didacticians knew this in advance, for the others it was new information. In selecting schools, there had been a wish to include some schools known to be interested in developing mathematics learning and teaching and others where this was not so evident. However, practical possibilities of working with only a small number of schools, the invitation to a relatively small set of schools in a mainly convenient location and selfselection of schools through volunteering for the project led to inclusion of a sample that was well-disposed to the project. Comments from individual teachers (one from each school respectively) provide more detail of the nature of being 'well-disposed'.

Sylvi: I joined [the project] because I thought it looked exciting, and then I have a colleague at my school who worked on the same subject, and the fact that we could discuss mathematics with others [teachers from other schools] ... then it 
looked exciting that you had focused on learning and communication. Yes, then our pupils are included in a larger community. [13]

David: I always think it's fine to get some fresh inputs and ideas in mathematics. That's why I wanted to be a part [of the project]. [2]

Egil: $\quad \ldots$ and at the same time, I was very interested in mathematics and had worked, maybe in a quite unstructured way. ... I wanted to go on working on mathematics and then this was a good opportunity to do it. [85]

These are mainly elementary schools, so teachers teach all subjects. All three, here, are keen to focus on mathematics. Typical of responses more generally are a desire for fresh inputs and ideas, tasks to use with their own class, opportunity to discuss mathematics with teachers from other schools and to develop further their own teaching and learning of mathematics. Particular to these schools is a wish to build on their background knowledge from earlier projects. In addition, Sylvi focused on terms like 'learning and communication' and 'community' [13] both central to conceptualization of the project and discussed in workshops.

The voices from the school administration gave the more general reasons for joining the project. The Principal at Stjernen focused on a bridge between the projects 'Fun with mathematics' and LCM, and pointed to a "most interesting" reason for joining the project:

Principal: ... what is one of the most interesting aspects of the project, is the cooperation we have [between the school and UiA] related to the field of practice. The fact that we have that interaction, it's not only UiA that informs the school, we also have something very important to inform you [didacticians] about, and you are interested in visiting our school. [104]

He speaks not only of cooperation but of a two-way cooperation which reflects an aim in the project that community should be a partnership between teachers and didacticians in which both bring knowledge and expertise and both learn from collaboration. The words above are expressed approvingly. They contrast with words from teachers in upper secondary schools which suggested the partnership was more one-sided with teachers offering more to the project than they received in return from didacticians as can be seen in quotations below.

\section{Teachers' perceptions from the project -- positive}

When the elementary school teachers look back and reflect after almost two years in the project (including 11 workshops) there seems to be a common view among them that they have greatly benefitted from participating in the activities of the workshops. The format of workshops involved a balance between plenary and small group activity. Plenary sessions included inputs from didacticians or teachers, or offered feedback and discussion sessions following small group activity. Small groups worked on specially designed tasks usually involving mathematical problems as well as opportunity to relate problems to classroom situations at all levels. They were organised on two formats, one being within a grade level, such as lower school or upper secondary, the other being across levels. Tasks 
(particularly mathematical tasks), groups and plenaries were key elements commented on by the teachers.

Analyses of perceptions of what the project had meant to teachers were interpreted within three main categories: mathematics and motivation; working with others in planning for the classroom, and inspiration for classroom activity.

\section{Mathematics and motivation}

Doing mathematics together, engaging in tasks in workshops, enjoying the fun, struggle and challenge all seemed motivating for teachers.

Fredrik: To sit and muse about different [tasks], all tasks are not that difficult. Some of them you've to think a lot, actually that's quite fun. [227]

Edvard: So we have been in these [small] groups, that I find very smart to do because you then discuss things together with others [teachers and didacticians], solve tasks in which you sit and struggle and in the beginning it's quite slow, what is it all about? This I don't understand, do we manage this? Then we start to work very hard on it [the task]. That's a lot of fun. [22]

Arnold: The ordinary school day is so hectic, ... so to have these hours on Wednesdays only to concentrate on mathematics, that is really a wonderful time. [140]

The emphasis on mathematics itself seemed new and enjoyable, and perhaps different from more usual focuses in professional development settings.

Fredrik: There is one more thing, that is the interest for mathematics as a subject. ... Mathematics is much more than just sitting in groups to discuss the mathematical problems. ... I think it is good for us as teachers of mathematics to like the subject in itself and not only to be so focused on methods, but on mathematics as a subject [215, 217, 221, 229].

Edvard: What I have noticed being a participant in LCM, I have not been a great mathematician, but I notice that I have been very thrilled with this. I think it's very exciting. ... There has been very much focus on training in reading and writing, but we should definitely have focused more on mathematics. [37]

Although not speaking of mathematics per se, the following voice emphasized motivation from the workshops:

Markus: These workshops at UiA, it has sometimes been difficult for us to go away [from our school], but when we have come to the workshops, it has been very meaningful and we have got a vitamin injection when we go home. [40]

\section{Working with others in planning for the classroom}

Teachers talked about the importance of discussing mathematics and of planning for the classroom with others, both of which seemed new to them within the project. Working in small groups with others, especially those working at the same level, makes mathematics 
more accessible. Inputs provide access to different areas of mathematics and plenary discussion allows access to ideas more widely.

Sylvi: When I come to a workshop - I am not a mathematician. Then something about equations is presented, and I think this is far beyond the scope of what I can manage. ... But when we go to groups, and for me to the early years group, we discuss it and make it easier and less dangerous. ... We adjust the theory down to my level. [182]

Fredrik: Those workshops at UiA, provide both a nice opportunity to cooperate with teachers from other schools and we discuss mathematics that can be used in our classrooms, actually we get lots of ideas from each other. [152]

Markus: I think something, eh in a way, well those workshops in which we have plenary sessions where we all listen and [discuss] the inputs and things like that. That's very valuable. [212]

Teacher spoke overwhelmingly positively about working with colleagues from the same grade at other schools and especially requested time at workshops to be given to joint planning for the classroom.

\section{Inspiration for classroom activity}

Even when talking about workshop activity, teachers’ focus was never far from the classroom.

Arnold: At each workshop there has been some background material about basic principles, hasn't there? What actually is probability? What is geometry?... We went home [from workshops] and went onto the floor in the [school] hall, looking for geometry and there was geometry everywhere. [134]

Agnes: The workshops at UiA are a great motivation for me ... a motivation to be a mathematics teacher and to develop and try out mathematics in the classroom. $[156,158]$

Teachers talked about use of workshop tasks in the classroom and ways in which they conceived of their use - not always as didacticians might have expected.

David: I have used many of those tasks presented in the workshops [in my own class]. ... Through discussions with other schools [at the workshops] we have also come up with teaching plans that have suited me ... It has been nice that we have got a task at UiA and tried to go into it and afterwards tried to adjust for our own class. ... I have got tasks that I would never have found out myself. [16]

Agnes: We find possibilities how to use the tasks in our classes, and ideas maybe in another way than you [didacticians] have considered. [498]

Video recordings from project classrooms testified to this statement more generally. Teachers found innovative ways of using workshop tasks and didacticians gained insights from viewing classroom video material into ways in which tasks designed for workshops 
could be modified for classroom use, and the kinds of outcomes for pupils. Here we see an example of reciprocity in the project, mutual learning between teachers and didacticians in a cycle of workshop $\leftarrow \rightarrow$ classroom; of design and planning $\rightarrow$ act and observe $\rightarrow$ reflect and analyze $\rightarrow$ feedback to design.

Teachers quoted above have mentioned the value of working with other teachers who teach at the same grade level. One voice however, from a teacher at lower secondary level, spoke up for the value of meeting teachers who teach as other levels.

Markus: When we sit and work in those groups [cross-grade], then we sit and work together with, for me the upper secondary [teachers]. Then I feel that I have quite another role ... then you must be explicit about how we work because you very quickly forget how you work in lower grades. I [also] think it has been valuable to work together with primary teachers, since then you can bring the best from variation in method and activity into the culture of lower secondary school. [214]

This comment speaks to the importance of discussing teaching with teachers from school levels other than your own. It is somewhat of a lone voice as we shall indicate below.

The above quotations chart perceptions of the project that show its positive side. However, there were also problematic areas and tensions that emerged through project activity.

\section{Teachers' perceptions from the project -- problematic}

Such perceptions overwhelmingly expressed tensions between visions of school activity projected by the project and the realities of school practice. In some cases, accommodation was acknowledged and appreciated; in others problems seemed not to be readily resolvable. The main categories of problem were constitution of small groups in workshops; finding time for project activity, and working as a project team within the school environment.

\section{Constitution of small groups in workshops}

As indicated above small group activity in workshops, including working on mathematics and on related aspects of didactics and pedagogy, was organised into two sorts of groups: same (or similar) grade groups and cross-grade groups. The latter were designed to foster understanding across the grade levels for the benefit of pupils who would work through them all. However, teachers at all levels, overwhelmingly, expressed a wish to work with others at the same grade, and so group constitution was changed accordingly.

Agnes: What I think has been very fine [in the project], that's, erm, something has happened in our meetings at UiA, since in the beginning we started to work in mixed groups across grade levels didn't we? ... But now we have groups for middle grades [5-7] and early years [Grades 1-4] that I think is very fine, ... since then it concerned me much more when I speak to teachers who have pupils in the same grades, almost in the same grades, and that is something you [didacticians] have changed during [the project]. [322, 324, 329, 334, 336, 339]

Fredrik: Yes, it is quite interesting at the workshops to listen to the teachers from higher secondary school, what they think and do [However I have] a feeling that we 
are on totally different planets. ... It seems as if there is a big gap between us, the way we work and what we focus on. $[581,583,585,588]$

The last quotation came from a teacher in response to a question from a didactician as follows:

Alf: If you work with teachers at different grade levels, then it's maybe easier to see how the mathematics is connected - for example as in solving equations? [574, 577][

Where teachers held strong views, they were not easily persuaded by didacticians. We had achieved ways of interacting which allowed for some frank speaking on the part of teachers: a measure of trust and respect within the community was that teachers felt able to speak frankly of what mattered to them, and where relevant to raise issues and be critical of events or circumstances, while didacticians tried hard to be responsive, modifying activity within the broad aims of the project.

In relation to the issue of two-way cooperation expressed earlier, such frank speaking is particularly emphasised in an interview in June 2005, between an upper secondary school teacher, Osvald and one of the didacticians:

Osvald: In many ways we feel that we have done a lot for you, but maybe not got enough in return. We have had the workshops which have been interesting, but we would like you to come up with some suggestions [for our work]. [27]

In the focus group interview at his school about one year later (060524), Osvald repeated that the workshops had been interesting, but he emphasized that the didacticians had something to learn from the teachers:

Osvald: ... I maybe think that you didacticians have a rather naïve perception about our pupils... you have an ideal aim, while we have to give you some realism (laughter) ... [463]

The quotation from the Principal at Stjernen [104] talked about each party "informing” the other. The quotation from Oswald talks of give and take, with an imbalance in which he sees the school doing less well than teachers wished from the project. Nevertheless in both cases, there was a strong sense of teachers recognizing the two-way nature of project participation and what each side 'gained' from the partnership.

\section{Finding time for project activity}

While teachers expressed that finding time to attend workshops was sometimes a problem, most teachers did attend workshops most of the time. This had been an important part of the agreement with schools and the project had paid a small amount to schools to facilitate attendance. It had also been agreed that the team of project teachers in a school would meet together regularly to plan for the classroom. However, finding time for activity in school was an issue harder to address. At face value, the issue reflected the busy-ness of the school day and the difficulty of finding hours or minutes to meet as a school team. 
Fredrik: What I think what has been difficult or problematic ... we haven't come up with I think good enough structures for those meetings that we should have [among] ourselves. ... so in order to find time for it, that's also an aspect that we haven't managed properly. [311, 315]

In response to a question at the Fjellet FGI about what has been difficult or problematic Sylvi responded:

Sylvi: I think the time, time, time, time, ... we have too little time to cooperate. [32] and later

Sylvi: After the meetings [the workshops at UiA], then it just disappears to the next time. Woh! Is it a KUL [LCM meeting] again? [Laughter] [107]

Markus: It was one of the reasons for having these school teams that we should find some time [to work together] [128]

Sylvi: Yes, we should have known that each Tuesday at 12 o'clock there would be a [school team meeting]. [129]

Asked by a didactician if he would like to participate in more research-based activity, David responded:

David: I feel there are so many things that happens everywhere that I have almost enough with what I must do. It seems interesting, but I think there is not time for it now. [208]

The principal at Stjernen made clear that problems are also recognized by the administration in a school.

Principal: We have talked about being visitors in each others' classes ... to observe, get new ideas and inputs, maybe after [the lesson] to discuss what has been tried out. ... It is important that the administration gives you opportunities to do this. ... Maybe Fredrik says that Wednesday in the fourth lesson I want to visit Agnes's class, then we must organize a substitute. [648, 650, 652, 654, 656]

However, we saw little evidence that such possibilities were put in place. The remark points to a more deeply rooted problem based in school structure and practice more generally as we show in the next section.

\section{Working as a project team within the school environment}

Organization in schools along year/grade lines made it hard for teachers at different grade levels to meet in school time.

Markus: That's at elementary school and that's at lower secondary school, the school day is organized differently.... [134]

Sylvi: Yes, what has been difficult, we haven’t we haven’t common breaks. [135] 
At Strand, organization is by "landscape” groupings in years 1-2; 3-4; and 5-7. Teachers work together within a landscape, which makes it harder to meet across landscapes.

Didactician Leo, questioned the Strand teachers as follows:

Leo: Just to clarify: When we consider [school teams in LCM] then we look upon you [LCM project members] as a team, sitting around a table. But in reality, is it the case that you attend your team and discuss LCM matters and of course other aspects, and you attend quite another team and discuss mathematics? [42]

David: What is most natural, ... there is little you have in common when you work among the youngest [pupils] and when you work among the oldest [pupils]. So it's more when I am going to prepare some teaching activities, then it suits me better to do this together with the other teachers [in my landscape team]. [43]

So, time is a general issue, and so is established school structure; however, making possibility for project teachers to meet in schools has also been a problem of concept. If time can be found and structures circumnavigated, what would the work in school involve?

Sylvi: I think we haven’t managed to establish a good team around this. I don't think we have managed to form a group that has regular meetings, no, it fades a bit away. [105]

The "it" that "fades away", might be seen as the motivation in or from a workshop. The Fjellet colleagues, who had the greatest distance to travel to workshops talked of the inspiration they gained from a workshop [Markus, 40] and the value of discussion together in the car on their return journey. Yet, they found themselves almost into the next workshop without any overt action having taken place in school [Sylvi, 107]. The principal at Stjernen talked of providing a substitute for teachers to visit each other in the classroom [656], but we gained no sense that this had been put in place. Frederik [311] said "we haven't come up with I think good enough structures for those meetings". This might be seen to address the nature of a meeting, as well as its structure. What should be addressed at such meetings and how?

An answer to this question emerges through what teachers say about communicating LCM ideas to other colleagues in their school. This seems to require some rationalization between the guiding principles of working within the school and what is seen to be valuable from LCM; for example, in Stjernen, where LCM ideas seem to support those of the school's Phase Model. The individual teachers at Stjernen had modified and tried out workshops tasks in their classrooms. This had set an example for others in the school as to how they might work in the Phase Model. The principal emphasizes what LCM has offered.

Principal: We have to be honest and say that it was you [teachers at Stjernen] who were a part of the LCM project, being at workshops, who tried out things in the classroom. ... There was not much work internally at our school. ... We have to do something here, to make a better structure and put this into the system. ... We want that all teachers at our school should work in this way. ... The Phase Model should be a standard for how we talk about mathematics and work with this subject. [631, 639, 642, 646] 
In Strand, with landscape teams, how have LCM teachers communicated with colleagues?

Edvard: It has been valuable to be at the workshops in which we have focused on a specific theme, working in small groups on tasks, discussing the tasks and adjusting them to our own class. ... I have also presented ideas from workshops at our own landscape meeting. I have done that once. [I] must spread ideas to the other teachers so maybe they can use them in their classes. [22]

Edvard: But do we manage to spread this focus on mathematics to the other teachers when there is only one person from each landscape team in the project? Do I manage to inspire what we have been working on, or is this only some interruption from Edvard in the landscape team? ... Or do we need more teachers [in the project]? I don't know? [35]

Arnold: Edvard has the main responsibility for mathematics in his grade level [Grade 1]. Then the two other teachers, as a minimum, can be pulled into his thinking. ... In addition, he [Edvard] is in a landscape with teachers of another grade level [Grade 2]. They will observe what Edvard's grade is doing and knowledge is spread to the other teachers. ... In addition, Edvard and Filip are now working on a 'learning-for-beginners' plan which should be followed by all the teachers in our school. Both of them have been in LCM... [39]

Thus, in both these schools, we see both principal and teachers linking LCM ideas with those in the school's own developmental model for all teachers. LCM ideas are starting to be fruitful in informing school-based activity through providing examples of what can be done. Issues are being addressed as to what a developmental programme in school can look like.

\section{Different roles of teachers and didacticians}

Two apparently contradictory forces were evident in the beginning of the project: the aim for developing co-learning partnerships between teachers and didacticians, and the facts of the project being designed, initiated and led (at least in the early stages) by didacticians. We have shown nevertheless elements of teachers' emerging voice and teachers' impact on the running of the project. Unsurprisingly, roles of teachers and didacticians in the project have been asymmetric: focus and interest, expertise and experience, for the two groups have been different. Asked to comment on the roles of teachers and didacticians, teachers pointed to key differences. Largely, and again unsurprisingly, these are interpreted as embedded in school life and provision for pupils (teachers) versus having an eye on the bigger picture (didacticians). This is reflected in the following extracts of dialogue from Strand.

David: Well, the good [thing] is that you sit a bit outside [in the workshops] and come up with questions that we maybe aren't thinking about ourselves. [166]

Edvard: I think it's very okay when it's in this way, that you are a bit in the background, but also come up with inputs... [171]

David: We need you [didacticians] to push us a bit further... [172] 
Arnold: Sometimes we wonder what you are doing. Our focus is the children, and I see that is not your focus. It is the thinking beyond that is the focus from UiA. Because you are not in contact with the children, in the same way as us. We are a link for your research, aren't we? $[180,185]$

Two teachers indicated a shift in their perception of the relationship in the early days and then later in the project.

Markus: In the beginning when you introduced the project, then I thought that, I don't know if I think differently today, that the didacticians' task [role] were to pose question concerning both practice and where we showed lack of reflection and to find good examples, to lay the foundation for making progress in the project. ... Later [in the project] this has maybe changed, that one sees to a much greater extent that one can learn from each other. ... You [didacticians] had presented ideas about this at the first time [workshop] at UiA in which this was a learning community, the fact that, in which one could learn from each other and in which one should experience equity or what I should call it. Erm, we are dependent on each other in order to get a good balance or a good interaction between theory and practice, well reflections on practice. [337, 339] [337-9]

Agnes: ... In the beginning [of the project] I struggled, had a bit of a problem with this because then I thought very much about you should come and tell us how we should run the mathematics teaching. That was how I thought, you are the great teachers ... but now I see that my view has gradually changed because I see that you are participants in this as much as we are even though it is you that organize. Nevertheless I experience that you are participating and are just as interested as we are to solve tasks on our level and find possibilities, find tasks, that may be appropriate for the pupils, and that I think is very nice. So I have changed my view during this time. And I think it's much better now, I feel myself much more comfortable, because now I feel that we are more equal than we were in the beginning from my point of view. [901, 903, 905]

Teachers' perceptions of didacticians expressed here show didacticians

- as having a different focus from teachers

- as offering questions that push teachers to think further;

- as having a research agenda that teachers can help to fulfil;

- as being the good teachers, laying the foundations.

All of these roles can be strongly supported from our data. These seem to be legitimate roles: roles that are necessary in simulating and promoting development. However, the last two voices speak of a shift in perception towards something translated as equity or equality. Didacticians were pleased to hear such comments as they seemed to fit well with notions of co-learning inquiry and inquiry community; that the relationships between teachers and didacticians had moved towards something more equitable, more of a partnership.

Perhaps the resolution of the implied tension here is in the interpretation of "equality". It is not that the roles of teachers and didacticians are the same, but that teachers have begun to 
experience their own power in the relationship and see a complementarity of roles rather than a hierarchy.

\section{Inquiry and Community - Achieving project aims}

The project set out to enable development in schools and classrooms with regard to mathematics learning and teaching. Both didacticians and teachers brought knowledge and expertise. Both had a lot to learn. As we have shown, it was didacticians' knowledge and expertise that guided the project in the early stages; gradually teachers' voices were heard and teachers started to influence the nature of activity. Possibilities for activity in schools were a strong influence on developmental activity and what was achieved. Didacticians had much to learn about the practicalities of realizing project aims. Some kind of equity of engagement was perceived by teachers, reflecting perhaps a recognition of mutual learning and the value in bringing together the alternative forms of expertise.

It seems clear from our arguments above and the representative data that a community was formed in which teachers and didacticians learned to work together and to tackle the issues that arose through joint activity. We see an inquiry process to be embedded in this mutual activity. Every step involved an exploration, both in workshops and in schools, and feedback from critical reflection guided future activity. The mathematical tasks in workshops were designed to be inquiry based. Thus engagement with a task involved mathematical inquiry. Teachers and didacticians engaging in tasks in workshops thus engaged in inquiry in mathematics. Teachers have spoken very positively both of their engagement in tasks in workshops and of their use of tasks with pupils: their modification of tasks to fit their own classroom circumstances is evident and goes beyond what didacticians could have designed for the classroom. Extensive video recordings from classrooms provide evidence of pupils' engagement in inquiry in mathematics. The word "inquiry" entered into project discourse, even when dialogue was in Norwegian. The following quotation provides an example of such dialogue. The teacher talks of differences between tasks for Grades 1-2 and those for Grades 5-7, but that inquiry provides a common frame.

Egil: Working in first and second grade is different, but the thinking behind is the same - the "inquiry" - it is nice to have that concept... Before, I had an unreflected attitude to what I was doing, but I did it because I felt it was good.... [Now we are more attuned to be in a process], and the process I think has been very confirming ... in respect of what you were doing as a teacher.... There is one thing that for me is the most important thing. That was at a meeting we had in December, when the school leaders were there, and we had a discussion about inquiry, and when you [a didactician] said "inquiry as a way of being”. That just put everything in place [for me].[255, 262, 277, 291, 296]

This teacher has since worked very closely with one didactician to develop activity in his classroom with a joint publication emerging (Jørgensen and Goodchild, 2007). Other such partnerships between particular teachers and didacticians contributed to growth of knowledge on both sides - co-learning. Learning in the project has centrally involved ways in which teachers and didacticians can work together for mutual development to improve classroom learning and teaching in mathematics. Some of the elements of this have been discussed above along with issues and tensions. Development overall is a slow process. 
We cannot point to large scale change in the schools in LCM. Many factors of school life had to be considered and might seem to have impeded development. However, we have to learn to work with such factors, or to recognize their problematic nature to such a degree that it becomes possible to facilitate changes. We see critical alignment to be a key factor in questioning the status quo and learning to work in collaborative inquiry ways within existing conditions (Wenger 1998; Jaworski 2006).

Before LCM ended, funding was granted by the research council for another project, largely designed to learn from and to follow LCM. This project (Teaching Better Mathematics - TBM) was established by the university in discussion with school owners (the Local Education Authorities) in the surrounding areas. TBM is owned by didacticians in UiA. However, a parallel project has also gained funding (Learning Better Mathematics - LBM) owned by the schools. Thus two projects work in concert with joint planning and complementary work between didacticians, school leaders and teachers. These projects offer opportunity to explore developmental possibilities in which both sides have initial power to design and direct activity. TBM now extends to five collaborating institutions wide spread in Norway, each with its own school partnerships.

As an endnote, what seems possibly more important in achieving an equitable developmental relationship is not so much provision for equal power as provision for equity in participation and learning. Analysis shows that the most powerful outcomes from LCM are new ways of thinking about what we do and how we do it. These are evident for both teachers and didacticians and are leading to new ways of thinking about joint activity and work with pupils. It will need a greater timescale, sustained commitment to the ideals and more widespread collaboration to achieve the kind of impact that can be seen in pupil outcomes. Such development needs commitment not only from universities and schools but from those who make educational policy. The funding of projects such as these by a national research council offers a first line of promise in this regard.

\footnotetext{
${ }^{1}$ The LCM project was accepted by the Research Council of Norway (RCN) as part of its KUL (Kunnskap, Utdanning og Læring) programme. Project number 157949/S20. LCM publications can be found at http://fag.hia.no/lcm/papers.htm

${ }^{2}$ Didacticians in the project were mathematics educators in a university in Norway, working within a department of Matematikk Didaktikk.

${ }^{3}$ Initially, the team had six members. We recruited two further colleagues, five doctoral students and a project coordinator and secretary. Thus the team became fifteen in all.
}

\section{References}

Bjuland, R. 2007. Adult students' reasoning in geometry: Teaching mathematics through collaborative problem solving in teacher education. The Montana Mathematics Enthusiast 4 (1): 1-30.

Borgersen, H.E. 1994. Open ended problem solving in geometry. Nordic Studies in Mathematics Education, NOMAD 2 (2): 6-35

Cobb, P., T. Wood, and E. Yackel. 1993. Discourse, mathematical thinking, and classroom practice. In Contexts for learning: Sociocultural dynamics in children's development, eds. E. Forman, N. Minick, and A. Stone, 91-119. New York: Oxford University Press. 
Cochran Smith, M., and S.L. Lytle. 1999. Relationships of knowledge and practice: Teacher learning in communities. In Review of Research in Education, eds. A Iran-Nejad and C.D. Pearson, 249-305. The American Educational Research Association.

Elliott, J. 1991. Action research for educational change. Milton Keynes: Open University Press.

Goodchild, S. (2008, in press). A quest for 'good' research: The mathematics teacher educator as practitioner researcher in a community of inquiry. In Jaworski B. (Volume Ed.) and Wood, T. (Series Ed.) Handbook of mathematics teacher education, Vol. 4 . The Netherlands: Sense Publishers

Jaworski, B. 1994. Investigating mathematics teaching. London: Falmer Press.

--- 1998. Mathematics teacher research: Process, practice and the development of teaching. Journal of Mathematics Teacher Education 1: 3-31.

--- 2003. Research practice into/influencing mathematics teaching and learning development: Towards a theoretical framework based on co-learning partnerships. Educational Studies in Mathematics 54: 249-282.

--- 2004. Insiders and outsiders in mathematics teaching development: The design and study of classroom activity. In Research in mathematics education: Papers of the British Society for Research into Learning Mathematics, eds. O. Macnamara and R. Barwell, Vol. 7, 3-22. London: BSRLM.

--- 2005. Learning communities in mathematics: Creating an inquiry community between teachers and didacticians. In Research in Mathematics Education: Papers of the British Society for Research into Learning Mathematics, eds. R. Barwell and A. Noyes, Vol. 7, 101-119. London: BSRLM.

---2006. Theory and practice in mathematics teaching development: Critical inquiry as a mode of learning in teaching. Journal of Mathematics Teacher Education 9(2): 187-211.

Jaworski, B., A.B. Fuglestad, R. Bjuland, T. Breiteig, S. Goodchild, and B. Grevholm. 2007. Learning Communities in Mathematics. Bergen, Norway: Caspar Forlag As.

Jørgensen, K. O., \& Goodchild, S. (2007). Å utvikle barns forståelse av matematikk. [To develop children's understanding of mathematics.] Tangenten, 1/2007 35-40 \& 49.

Kelly, A.E. 2003. Research as design. Educational Researcher 32 (1): 3-4.

Mason, J. 2001. Researching your own classroom practice. London: Routledge Falmer.

Mason, J., L. Burton, and K. Stacey. 1982. Thinking mathematically. London: Addison Wesley.

Polya, G. 1945. How to solve it. Princeton, NJ: Princeton University Press.

Wagner, J. 1997. The unavoidable intervention of educational research: A framework for reconsidering research-practitioner cooperation. Educational Researcher 26 (7): 13-22.

Wenger, E. 1998. Communities of practice, Cambridge: Cambridge University Press. 
Wood, T. and B. Berry. 2003. Editorial: What does "Design Research” offer mathematics teacher education? Journal of Mathematics Teacher Education 6 (3): 195-199. 